\title{
The Field Trip as Part of Spatial (Architectural) Design Art Classes
}

JANJA BATIČ ${ }^{1}$

$\approx$ Spatial (architectural) design is one of five fields introduced to pupils as part of art education. In planning architectural design tasks, one should take into consideration the particularities of the architectural design process and enable pupils to experience space and relationships within space through their own movement. Furthermore, pupils should have an opportunity to play the roles of (critical) users as well as co-creators or spatial planners. In this respect, the field trip plays a vital role, as it allows pupils to experience (architectural) space through their own movement, their senses and in a real environment. The architectural experience that the pupils gain differs from their everyday experience of moving through space, as the former is based on education and training, and thus helps pupils develop architecture appreciation.

Keywords: Architecture appreciation, Art education, Field trip, Spatial (architectural) design, Spatial experience

\section{Introduction}

Spatial (architectural) design is one of five art forms taught as part of elementary school art education. The scope of these art classes is to introduce pupils from the first grade onwards to basic architectural concepts. The pupils redesign space and make models, while becoming acquainted with the evaluation of various architectural spaces. They develop their sensitivity towards the way a space is arranged, with regard to both its utility and its artistic value. When planning art tasks in architectural design, one should start from the specific nature of the architectural design process, with regard to which experience gained by means of one's own movement through space is particularly important. Pupils can gain such experience on a short excursion or field trip.

1 Faculty of Education, University of Maribor

janja.batic@uni-mb.si 
In the continuation, we describe some particularities of spatial (architectural) design as an art form and the role of movement through space with regard to the perception and understanding of space (natural space as well as constructed space) as a whole. We also highlight the significance of the field trip with respect to the planning and execution of spatial (architectural) design tasks, through which pupils can gain experience as well as exploring and experiencing architectural space with all of their senses.

\section{Spatial (architectural) design in art education}

In elementary school art classes, pupils are introduced to five art forms: drawing, painting, sculpting, graphics and spatial (architectural) ${ }^{2}$ design, whereby the latter is distinguished from other art forms by its function. Architecture is considered to be functional art, as it confines space so that we can dwell in it, thus creating the framework around our lives. Even the most abstract sculpture, limited to purely geometric shapes, is not architecture, for it lacks utility (Rasmussen, 1959). Furthermore, architecture is unavoidable art, as it surrounds us on every step, shaping the way we feel and determining our mood (Roth, 1993). Whether we are inside buildings or outdoors, we are inseparable from space (Lawson, 2001).

Elementary school art classes are designed so that pupils can learn various concepts regarding spatial design. They can design architectural structures or models as well as developing and advancing their ability to observe space. Furthermore, they should become more conscious of environments that are well organised, develop a feeling for the sensible arrangement of spaces and nurture an ability to design spatial forms of their own invention. Pupils should also develop a critical attitude towards an uncontrolled environment, as well as a feeling for artistically designed architectural space (Učni načrt, 2004). Thus, pupils should gain knowhow and experience enabling them to evaluate the utility as well as the aesthetic value of architectural space with a critical eye. Architecture is basically intended for users; however, Lawson (2001) criticises architects for frequently being more interested in buildings than their users. He gives an interesting example to illustrate this, drawing attention to the fact that architectural magazines rarely show people, or the users of a particular space,

2 The curriculum defines this field rather broadly, as the scope of spatial design art classes to some extent also includes stage or film set design, theatre and theatrical plays, as well as the importance of cultural heritage and its preservation. However, the main goals remain focused on the architectural design process. 
in the photographs reproduced on their pages. Rasmussen (1959) came to a similar conclusion much earlier, claiming that one proof of good architecture is when it is used as planned by the architect.

In art classes, pupils themselves take on the roles of (critical) users as well as co-creators or spatial planners/designers. As designers, they observe architecture in a familiar environment, suggest changes, make models based on their own ideas, etc. This means that, on an elementary level, pupils learn about the architectural design process. According to Ching (1996), problem recognition and the decision making involved in finding a solution are the first steps in any design process. The designer must first document the existing circumstances of the problem and define the context, as well as collecting and analysing any relevant data. Two prerequisites for recognising an architectural design problem are the perception and understanding of architectural space.

\section{The Perception and understanding of (architectural) space}

Perception is important in that it informs us about the properties of the environment that are significant for our survival, as well as building our attitude towards the environment (Goldstein, 2002). Pečjak (2006, p. 65) claims that a human being perceives space through four senses: sight, hearing, touch and the kinaesthetic sense, of which sight is the most important. According to Bonča (1994, p. 38), it is body movement ${ }^{3}$ that enables us to acquire information on those segments of space that we cannot capture with one glance. Furthermore, it is movement that helps us to create some sort of network of spaces, in which different facilities appear in a certain relation and at definite distances as movement trajectories (Tomšič Čerkez \& Zupančič, 2011, p. 25). With regard to perception, Rasmussen (1959) underlines the significance of experience. One needs to experience architecture, that is, observe the way a building has been designed for a particular purpose and walk through it, in order to gain a sense of the acoustic features of a particular room. Lawson (2001) claims that speed of movement plays an important role in reading an architectural object, as our experience changes depending on whether we walk slowly past a building or

3 Certain studies of the way children perceive space and spatial relations have highlighted the role of the individual's own movement in space, which helps children to develop a sense of spatial relations (such as: near, far, left, right, before, behind, etc.) in order to orient themselves and to develop accurate perception of space (cf. Hazen, Lockman \& Pick, 1978; Reieser, Garing \& Young, 1994). 
drive by it. This is illustrated with the example of a pedestrian moving with a more or less constant speed. »The way buildings appear and move across our field of vision is largely dependent on this pace of life. As pedestrians we may walk directly past buildings, perhaps on the pavement of a street. In such circumstances we may not only be able to reach out and touch them, but also to feel their effects in a wide variety of ways. We might sense the change in temperature as they create shade or perhaps shield us from the wind; we may hear the sounds of the city reflected back off the walls; we may even smell the materials of the building or the preparation of food or other processes inside" (2001, p. 55). We do not only experience architecture through our eyes, we perceive space with our hearing as well. Blesser and Salter (2007) argue that we do not require any particular skills for this purpose. They claim (ibid.) that when blindfolded nearly all of us can approach a wall without touching it, simply by being attentive to how the wall changes the frequency balance of the background noise. Sound influences our perception of space even though we are not aware of it. For example, the acoustics of a grand cathedral can create an exalted mood, those of a chapel can enhance a feeling of privacy and quiet contemplation, those of an elevator can produce a feeling of encapsulation, whereas the acoustics of an open area can produce feelings of either freedom or insecurity (ibid.). Nevertheless, the perception of space and spatial relations with our eyes is completely different from the perception of space and spatial relations without visual experience. ${ }^{4}$

Norberg-Schulz (1997) compares the everyday experience of an individual to that of a tourist. Rushing to and from work every day, the buildings we pass create a relatively neutral background. Although this does not mean that these buildings are irrelevant, it does show that we limit ourselves to sensing

4 In her book Na drugi strani vek (a description of first-person phenomenological research on being blind), Aksinja Kermauner describes her perception of space while subjecting herself to self-imposed blindness (wearing a blindfold). She reports that initially she was completely confused and could not determine the shapes of the rooms. Later, she gained better control of space, although she had to be attentive to orientation points in order to be able to determine where she was at any given time. She drew the ground plan of the house she was living in on a positive film. At the end of the test, she removed the blindfold and compared the space she saw with her eyes with the space she had experienced earlier with her other senses. She discovered that her earlier perception was inadequate compared to the real physical space. The rooms felt considerably bigger when blindfolded and she could not determine the exact ground plan or the way the rooms were organised. There was something organic in the way they were arranged around her and she felt they were moving constantly, yet she did manage to come up with an approximate layout of the rooms (Kermauner, 2009, p. 48). 
only some of their features. Butina calls this visual viewing and thinking, which he claims is spontaneous and non-reflected. For example, walking from the Ljubljana train station to Mestni trg we pass certain parts of the city that, in terms of architecture, reflect the cultural milieu of the time in which the buildings were built. In other words, we are on a journey through people's thinking and perception of the world and society in past eras, but we are not normally aware of this, instead noticing merely buildings, streets and traffic (1997, p. 137). However, our attitude changes as soon as we take part in an activity that directly concerns a building, e.g., when we view a building as a tourist. Norberg-Schulz says (ibid.) that we orient ourselves with regard to the situation, so our architectural experience is changing and versatile, even though the notion itself is rarely used in this sense. However, the notion of architectural experience is frequently used in the sense of experience that is not restricted to a single situation but refers to architecture as a whole, or to an entire cultural building or facility. In this case, our experience is based on the schema of searching for forms that we, as individuals, are accustomed to and that coincide with the fact that we tend to see only that which we expect to see. According to Smith (2003), our judgement of a new building is based on certain templates, and when a building deviates from these considerably we reject it and consider it a mistake. Norberg-Schulz (ibid.) labels these templates or schemata as prejudice, as we tend to apply them to architecture of a different time and space. Moreover, he says that most people easily define a building as either beautiful or ugly, which goes to show how superficial their perception is. Therefore, he believes that architectural experience should be based on education and experience, whereby the goal is to learn to see and thus understand the language of design and the meaning of forms. Considering the fact that architectural forms are essential components in our milieu, learning about architecture and its evaluation (i.e., appreciation of architecture) should be made part of elementary school education (Norberg-Schulz, 1997).

Furthermore, this has been included in the elementary school curriculum (Učni načrt, 2004) together with cognitive goals (e.g., learning about architectural concepts) and affective goals (such as imparting a sense of function and aesthetics with regard to form, raising awareness of the use of natural construction materials, developing a sense of artistically designed architectural space, and developing a feeling for balance of mass and for harmony of material, colour and surface). Betty Oliver Seabolt (2001) claims that only once both cognitive and affective goals have been achieved can we arrive at art appreciation that is the result of the entire process, signifying that one understands and enjoys art. Duh (2004) notes that artistic expression and art appreciation play 
an equally important role. Furthermore, he establishes (ibid., p. 44) that while Slovenian children of all ages are encouraged through institutionalised education to freely express themselves artistically, there is little attention dedicated to art appreciation. The two are not, however, directly connected, as, according to Barrett (2007), making something does not necessarily imply appreciation of the result: if artmaking results in a negative experience this might be reflected in a negative response, yet when the experience is positive this does not necessarily secure the pupil's appreciation. Appreciation is a complex act of recognition; full appreciation involves engagement with the artwork in a way that comprises not only knowledge of various sorts but also emotion that informs knowledge (Barrett, 2007 quoting Scheffler, 1991). Art education in elementary school, as well as in the preschool ${ }^{5}$ period, should include art appreciation in addition to artistic expression.

Planning art classes that incorporate perception, understanding and appreciation of architectural space requires the use of various teaching methods and forms, the most prominent being those that enable perception and understanding of space and spatial relations through the individual's own movement. One possibility is to organise a field trip, which, according to Babić (1978), enables pupils to perceive things that they have only been able to see as reproductions in the classroom in a real-time environment. This is particularly relevant with regard to architecture, which can be experienced much better on a field trip than through viewing photographs.

\section{The field trip in spatial (architectural) design}

Perceiving space through one's own movement is something completely different from viewing photographs or videos in class. We can enable pupils to have such an experience by organising a didactic field trip during which they can perceive objects in their natural environment and with their natural connections (Cencič \& Cencič, 2002, p. 131). This makes the whole thing more explicit, which, according to Strmčnik, involves the active perception of the world through all sensory channels, including the kinaesthetic sense, which tends to be neglected (2003, p. 192). The author also notes that when straightforward reality is slighted it is more difficult for pupils to fathom it rationally and in terms

Epstein and Trimis (2002, quoted in Eckhoff, 2008) caution that preschool teachers should be familiar with terminology as well as with strategies to incorporate art appreciation activities, as this is the necessary first step to sharing the experience of art appreciation in the preschool period. 
of its value, as they are unable to observe its natural relations and connections with the environment (ibid., p. 194). The objectives and value of gaining knowledge outside the classroom are: active learning outdoors, motivating pupils with new and enjoyable experiences, developing their research skills as well as their skills of observation, taking notes, in situ analysis, gaining knowledge and understanding with regard to "real world « context, developing sensitivity to the environment, etc. (Catling, 2010). Research on the effect of field trips in natural science subjects points to an important advantage; namely, students tend to retain the knowledge acquired on a field trip (cf. Morrell, 2003). Educational field trips enable pupils to gain new experience and make them more aware of the world in which they live (Nabors, Edwards \& Murray, 2009).

Some less recent authors have dealt with the classification of educational excursions. Šilih (1961), for example, classified them into educational walks (the objective of these is normally a specific problem and they are frequently used in elementary and secondary schools), field trips (which normally last one school day and incorporate intersubject connections), and school journeys (more complex excursions that last several days). On the other hand, Babić (1978) distinguishes between nomadic excursions (shorter visits of a single location, perhaps resulting in superficial observation) and stationary excursions (bound to a certain location), noting that of all of the fields of art it is architecture that can only be experienced fully through a field trip.

On the other hand, Izumi Taylor, Gunn Morris and Coureau-Young (1997) specify short walks that are appropriate for younger children:

- Within the school building. Pupils might visit the head teacher's office, the kitchen, etc.

- $\quad$ Outside the building. Pupils might view the school building on the outside and the adjacent buildings.

- Walks through the school site. Pupils view the buildings in the school's vicinity that have different purposes (e.g., hospital, shop, petrol station).

An educational walk through the school building as part of architectural design classes enables pupils to have a look at different school areas (classrooms, studies, hallways, staircases, etc.) or to observe the school site and the buildings in its vicinity. According to Milena Ivanuš Grmek, a school yard may function as a space that completes other school facilities, contributing to the realisation of school goals, in particular those related to the culture of living and dwelling (2003, p. 328).

The space with which pupils are familiar represents the basis. Beatriz Tomšič Čerkez notes that raising awareness with regard to the values of space in 
light of sustainable development must begin in pupils' and students' home places, which they have come to know through their everyday experience (2007, p. 29).

The purpose of an educational walk in spatial (architectural) design art classes is for pupils to experience space through their own movement, to asses the utility of individual areas as well as their aesthetics. Such a walk might also serve as the basis for solving art assignments in architectural (spatial) design. Thus, pupils can identify a certain architectural (spatial) problem just by moving through space on their own, and subsequently suggest improvements. ${ }^{6}$ In this case, pupils take part actively in the creation of an art assignment, as the assignment itself is based on a problem that they have sensed themselves in a certain situation as users of architectural space. However, an educational walk may also serve as an introduction to a task with a more complex scope, its objective being the redevelopment of pupils' sensitivity towards space and spatial relations, identifying different architectural elements and similar.7 The goal of an educational walk in spatial (architectural) design is for pupils to gain their own experience by means of moving through either a familiar space or an unfamiliar space indoors or outdoors, whereby they perceive and experience space through all of their senses. The planning and execution of spatial (architectural) design classes based on the pupils' own experience results in their improved appreciation of the architectural milieu (cf. Hickman, 2001).

6 The experience pupils gain during an educational walk might be reflected in their work. Action research we have conducted with fifth graders (elementary school) proves this point. The pupils were taken on a walk during which they photographed those parts of the school building and its vicinity that they disliked. Subsequently, they showcased their ideas in redesigned photographs. When later given a new assignment and a new problem, the pupils incorporated some details from the redesigned photographs onto the new sketches and models presenting their solutions (cf. Batič, 2010).

7 A case study involving two classes of first-graders (elementary school) and their teachers proves this point. The objective of this research was to highlight which art activities are suitable for including spatial (architectural) design topics, and to determine how these can be incorporated in the artmaking of six-year-olds. We planned and executed a thematic cluster (architectural space) in which pupils were able to experience a known spatial actively by moving through it, observing it, and finally, transposing their experiences into a drawing. As part of sculpting, the pupils engaged with rhythm, which is a compositional element that pupils normally tend to feel very strongly within architectural space (repetition of windows, balconies, etc.). In graphics, architectural space appeared as a part of a motif, representing a kind of scene for the happening, while painting in oil pastels onto black and white photographs was used for planning the changes to be made in the familiar environment. Finally, pupils made a model of a school of the future from floral foam, corrugated cardboard, and sticks (cf. Batič \& Herzog, 2009) 


\section{Organisation of a field trip, teaching methods and aids}

Regardless of whether the planned field trip is a short educational walk or an extensive excursion, it should be organised and executed properly. Each field trip should have clearly defined goals, objectives and a plan of execution (Roca, 1979). Furthermore, the field trip should ensure that pupils learn from the experience. Andrea Sabatini McLoughlin (2004) cautions that younger teachers often focus on the execution of a field trip, that is, how to bring pupils from one location to another, thus neglecting the planning of the activities to be undertaken before, during and after the field trip. According to Roca (1979), regardless of the length of the field trip an art teacher is expected to study the conditions, decide on the content and ensure the necessary aids, all in order to ensure that lessons outside the classroom will not be conducted in a disorganised or unbridled manner.

The use of aids on a field trip depends on the approach chosen by the teacher. Kimber and Smith (1999, quoted by Catling, 2010) identify five options: research activity in a preselected space (e.g., pupils observe a specific object such as an exhibit piece at a museum), research activity based on inquiry, problem solving (e.g., pupils find a 'problematic' area and search for ways to improve it), enacting (pupils use role playing to illustrate how people live/d in a different place/time), a guided walk (teachers choose a specific route for pupils, along which they are exposed to particularities that they should observe and note down on their worksheets). As part of spatial (architectural) design classes, pupils can (depending on the curriculum goals for each class) research the equipment and its arrangement in class or other facilities (school cafeteria, gymnasium, locker room, etc.) from the point of view of utility and artistic arrangement, and they can also discover special features outdoors (playground, school yard, parking area). Some teaching aids pupils might use are ready-made worksheets, pens and drawing tools. We can encourage pupils' observation by composing a worksheet that includes photographed details of individual architectural elements; their task is to locate those details on the actual buildings. This is to ensure that pupils' attention is focused on a specific element, while at the same time stimulating their interest and their drive for discovery. Another aid pupils might use during such an educational walk is a camera, enabling them to take photographs of certain views or details (depending on the art assignment). Although this might have been a problem in the past, pupils nowadays frequently have mobile phones that can take photographs or shoot short videos. 
A didactic field trip is closely associated with the demonstration meth$\mathrm{od}^{8}$ as well as observation (Roca, 1979). According to Kramar, this method is about realising the principle of explicitness through the logical intertwining of sensory perceptions with mental and physical (psycho-motoric) activities (2003, p. 368). During a field trip, pupils observe, learn about and experience architecture, combining their sensory perception with reason. Strmčnik (2003) claims that we use our senses to fathom that which we see, while our reason and logic enable us to comprehend in-depth relations. Both are then merged in a single cognitive process.

According to Tacol, the demonstration method is successful when combined with the methods of discussion and explanation (2003, p. 100). It is for this reason that when organising a field trip one needs to prepare a special form of the discussion method with which we encourage pupils to consider purpose, arrangement, forms, colours, and materials. The term used in books is "art investigation methodology «. ${ }^{9}$ Rebecca Shulman Herz (2010) describes the use of this particular method as follows: prior to viewing artworks, the teacher prepares three to five open-form questions, the objective of which is to stimulate, firstly, pupils' observation and, secondly, their interpretation. Furthermore, the teacher encourages pupils to search for connections between an artwork and their personal lives and experiences from other spheres of life. Pupils should have enough time to answer the questions, while the teacher should encourage them to provide arguments for their thoughts. Moreover, the teacher is expected to provide information on the observed artwork at critical points of the discussion, thus enabling a better understanding of the artwork concerned. Such investigation and discussion will lead to pupils developing their own thoughts and producing ideas and interpretations the teacher cannot foresee in advance (ibid., 2010). Architectural design as part of art education is about pupils

8 Various authors have used several names for this: the illustration and demonstration method (Filipović, 1988), where illustration refers to showing objects, drawings, paintings, etc. and demonstration refers to dynamic reality; the illustrative and demonstration method (Tomić, 2003); the representation method (Kramar, 2003); depiction (the demonstration method) (Tacol, 2003); the method of demonstrating (Duh \& Vrlič, 2003), etc.

9 This method is used in class but originates from museum pedagogy and is based on research and partly on constructivism. The acquired knowledge is the intersection of what pupils already know and the newly acquired ideas and knowledge. For art teachers, this means that they can offer their pupils a chance to connect their ideas and knowledge to the art activities they have previously undertaken, thus creating new meaning. The above method (»The Guggenheim Museum's Art Investigation Methodology«) is one example of such an approach (Shulman Herz, 2010). 
discovering the architectural space by investigating purpose and utility, form, size, artistic arrangement, interior and exterior furniture, etc. The teacher must create the conditions for the individual to be able to express his or her views and judgements and to develop his or her sensitivity with regard to the perception and understanding of aesthetic messages. The latter may be realised by two specific methods used in art education: the method of aesthetic cultivation and the method of expansion and elaboration of art sensitivity, both of which derive from the specific nature of aesthetic communication (Karlavaris, 1987).

\section{Conclusion}

Modern technology with the World Wide Web has flooded classrooms with images, photographs of artworks, video clips and virtual galleries. However, that which it foregrounds is merely a substitute for reality. A photograph or video, no matter how good it might be, only carries information on the appearance of, for example, a building. We cannot walk through it, touch it, check the acoustics, make judgements on its utility, etc. Yet even a short field trip can enable all of these. Pupils can gain their own experience of architectural space, which can later serve as a basis for planning a spatial (architectural) design task. Thus, the art problem derives from real experience and the pupils take part in the co-creation of the architectural design task.

When combined with certain general or specific methods, the spatial (architectural) design field trip may prompt the perception, experience and evaluation of architectural space, all of which contribute to the development of pupils' appreciation of architecture, also enabling their knowledge to be complemented with emotions. Thus, instead of being the result of prejudices or acquired schemas, a pupil's architectural experience can derive from training and education.

\section{References}

Babić, A. (1978). Promatranje likovnih djela u osnovnoj školi. Zagreb: Školska knjiga.

Batič, J., \& Herzog, J. (2009). Arhitekturni prostor u likovnom izražavanju šestogodišnjaka. In L. Vujičić, \& M. Duh (Eds.), Interdisciplinarni pristup učenju, Put ka kvalitetnijem obrazovanju djeteta (pp. 17- 29). Reka: Učiteljski fakultet, Maribor: Faculty of Education.

Batič, J. (2010). Arhitekturno oblikovanje pri likovni vzgoji v osnovni šoli. Ljubljana: Genija. Barrett, T. (2007). Teaching Toward Appreciation in the Visual Arts. In L. Bresler (Ed.), International Handbook of Research in Arts Education (pp. 639-654). Springer International Handbooks of Education. Retrieved February 13 2011, from SpringerLink. Blesser, B., \& Salter, L. R. (2007). Spaces Speak, Are You Listening?: Experiencing Aural Architecture. 
Cambridge: MIT Press.

Bonča, J. (1994). Prostor spoznavamo, kakor se skozenj gibljemo. Likovne besede, 26/28, 37-44.

Butina, M. (1997). Prvine likovne prakse. Ljubljana: Debora.

Catling, S. (2010). Organising and Managing Learning Outside the Classroom. In J. Arthur, \& T.

Cremin (Eds.), Learning to Teach in the Primary School (2nd edition) (pp. 159-178). London and New

York: Routledge, Taylor \& Francis Group.

Cencič, Ma., \& Cencič, Mi. (2002). Priročnik za spoznavno usmerjen pouk. Ljubljana: Mladinska knjiga.

Ching, F. D. K. (1996). Architecture: Form, Space \& Order. New York: John Wiley \& Sons, cop.

Duh, M., \& Vrlič, T. (2003). Likovna vzgoja v prvi triadi devetletne osnovne šole: Priročnik za učitelje razrednega pouka. Ljubljana: Rokus.

Duh, M. (2004). Vrednotenje kot didaktični problem pri likovni vzgoji. Maribor: Faculty of Education,

FEd Publishing.

Eckhoff, A. (2008). The Importance of Art Viewing Experiences in Early Childhood Visual Arts:

The Exploration of a Master Art Teacher's Strategies for Meaningful Early Arts Experiences. Early Childhood Education Journal, 35(5), 463-472. Retrieved January 31 2011, from ERIC.

Filipović, N. S. (1988). Didaktika 1. Sarajevo: IGKRO „Svijetlost«, OOUR Zavod za udžbenike.

Goldstein, E. B. (2002). Sensation and Perception. United States of America: Wadsworth-Thomson Learning, cop.

Hazen, N. L., Lockman, J. J., \& Pick Jr., H. L. (1978).The Development of Children's Representations of Large-Scale Environments. Child Development, 49(3), 623-636. Retrieved November 14 2005, from Academic Search Premier.

Hickman, R. (2001). School Students' Responses to Architecture: A Practical Studio Project.

International Journal of Art \& Design Education, (20)2, 161-170. Retrieved August 20 2008, from Academic Search Premier.

Ivanuš Grmek, M. (2003). Učni prostor. In F. Strmčnik (Ed.), Didaktika (pp. 322-328). Novo mesto:

Higher Education Centre, Institute for Research and Development Work.

Izumi Taylor, S., Gunn Morris, V., \& Cordeau-Young, C. (1997). Field Trips in Early Childhood Settings: Expanding the Walls of the Classroom. Early Childhood Education Journal 25(2), 141-146.

Retrieved February 6 2011, from SpingerLink.

Karlavaris, B. (1987). Problemi učnih metod pri likovni vzgoji. Sodobna pedagogika 38(3-4), 179-183. Kermauner, A. (2009). Na drugi strani vek: (opis prvoosebne fenomenološke raziskave - kako je biti slep). Ljubljana: Študentska založba.

Kramar, M. (2003). Metodične strani izobraževalnega procesa. In F. Strmčnik (Ed.), Didaktika (pp.

329-419). Novo mesto: Higher Education Centre, Institute for Research and Development Work.

Lawson, B. (2001). The Language of Space. Oxford: Architectural Press.

Morrell, P. (2003). Cognitive Impact of a Grade School Field Trip. Journal of Elementary Science

Education, 15(1), 27-36. Retrieved February 6 2011, from SpringerLink.

Nabors, M. L., Edwards, L. C., \& Murray, R. K. (2009). Making the Case for Field Trips: What 
Research Tells Us and What Site Coordinators Have to Say. Education 129(4), 661-667. Retrieved January 31 2011, from ERIC.

Norberg- Schulz, C. (1997). Intentions in Architecture (10th edition). Cambridge: MIT Press.

Oliver Seabolt, B. (2001). Defining Art Appreciation. Art Education, 54(4), 44-49. Retrieved February 13 2011, from ERIC.

Pečjak, P. (2006). Psihološka podlaga vizualne umetnosti. Ljubljana: Debora.

Predmetna kurikularna komisija za likovno vzgojo (2004). Učni načrt: Likovna vzgoja. Ljubljana:

Ministry of Education and Sport of the Republic of Slovenia, The National Education Institute of the Republic of Slovenia.

Rasmussen, S. E. (1959). Experiencing Architecture. Cambridge: The MIT Press.

Roca, J. (1979). Likovni odgoj u osnovnoj školi. Zagreb: Školska knjiga.

Roth, M. L. (1993). Understanding Architecture: Its Elements, History and Meaning. London: The

Herbert Press.

Sabatini McLoughin, A. (2004). Engineering Active and Effective Field Trips. Clearing House, $77(4)$, 160-163. Retrieved January 31 2011, from ERIC.

Schulman Herz, R. (2010). Looking at Art in the Classroom: Art Investigations from the Guggenheim

Museum. New York: Teachers College, Columbia University.

Smith, F. P. (2003). The Dynamics of Delight: Architecture and Aesthetics. London and New York: Routledge, Taylor \& Francis Group.

Strmčnik, F. (2003). Didaktična načela. In F. Strmčnik (Ed.), Didaktika (pp. 166-225). Novo mesto:

Higher Education Centre, Institute for Research and Development Work.

Šilih, G. (1961). Didaktika. Ljubljana: DZS.

Tacol, T. (2003). Likovno izražanje: Didaktična izhodišča za problemski pouk likovne vzgoje v

devetletni osnovni šoli. Ljubljana: Debora.

Tomić, A. (2003). Izbrana poglavja iz didaktike (fourth extended edition). Ljubljana: Faculty of Arts

Centre for Pedagogical Education.

Tomšič Čerkez, B. (2007). Prostorsko oblikovanje med »virtualnim« in »realnim«. Likovna vzgoja, $8(37-38), 24-30$.

Tomšič Čerkez, B., \& Zupančič, D. (2011). Prostor igre. Ljubljana: Faculty of Education and Faculty of Arts of the University of Ljubljana Publishing. 


\section{Biographical note}

JANJA BATIČ, $\mathrm{PhD}$, was born in 1977 in Maribor. In 2001 she graduated from the Faculty of Education, University of Maribor, Department of Art Pedagogy. She continued with the studies of Art Pedagogy at the Faculty of Education, University of Ljubljana, where she obtained her Master's Degree in 2006 and her PhD in 2010. Since 2002 she has been employed at the Faculty of Education, University of Maribor. 